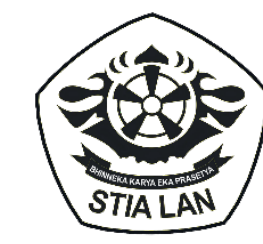

Jurnal Administrasi Negara, Volume 26 Nomor 1, Edisi April 2020

Jurnal

STIA LAN MAKASSAR

Administrasi Negara

\title{
DETERMINAN KEBERHASILAN REFORMASI SISTEM KEPEGAWAIAN DI CHINA PERIODE 1980-2010
}

\section{DETERMINANTS OF SUCCESSFUL CIVIL SERVICE REFORM IN CHINA 1980-2010 PERIOD}

\author{
Ramadhani Haryo Seno \\ Fungsional Analisis kebijakan Ahli Pertama \\ Sekretariat Jenderal Kementerian ESDM \\ dhaniharyo.seno@yahoo.com
}

\begin{abstract}
Abstrak
Penelitian ini diarahkan untuk menggambarkan proses reformasi kepegawaian pada suatu negara, dengan menemukan faktor determinan dalam melakukan tranformasi dan pengembangan sistem kepegawaian sebuah negara. Teknik analisis data yang digunakan ialah analisis deskriptif kualitatif dengan mengkombinasikan penelitian kepustakaan dan menelaah data sekunder sebagai metode pengumpulan data. Hasilnya menunjukan bahwa terdapat empat faktor determinan dalam keberhasilan China mereformasi sistem kepegawaiannya yaitu: faktor politik, hukum, birokrasi, dan ekonomi. Sementara itu pembelajaran baik yang dapat diadopsi dari setiap faktor ialah (1) faktor politik seperti komitmen, konsistensi, dan kapasitas pimpinan (2) faktor hukum seperti; penciptaan aturan main, pengawasan, dan penciptaan stabilitas, (3) faktor birokrasi seperti: profesionalitas, penerapan sistem merit, dan peningkatan kesejahteraan, serta (4) faktor ekonomi seperti: pemilihan kebijakan yang pragmatis dan pembangunan ekonomi yang mendorong investasi.
\end{abstract}

Kata Kunci: Reformasi sistem kepegawaian, Proses Reformasi, Politik, Hukum, Birokrasi, dan Ekonomi

\begin{abstract}
Focus of this research is to describe civil service system reform process in one country, by finding the detreminants of successful factors in transforming and developing civil service system in China. Descriptive qualitative analysis by study literature and examining secondary data as a data collection method use in this research. The result show that there are four determinants of successful: political, legal, bureaucratic, and economic factors. Best practices can be adopted from every factor (1) The political factors such as commitment, consistency, and leadership ability (2) The legal factors such as; Related to the main rules, supervision, and approval, (3)The bureaucratic factors such as: professionalism, implementation of a merit system, and improving welfare, and (4) The economic factors such as: pragmatic policy selection and economic development that encourage investment.
\end{abstract}

Key words: Civil service reform, reform of process, pollitical, legal, bureuacracy, dan economics. 


\section{PENDAHULUAN}

Menurut statistik resmi Cina, selama 30 tahun terakhir dari 1978 hingga 2008, produk domestik bruto (PDB) Tiongkok tumbuh pada tingkat rata-rata tahunan 9,8 persen, menjadikan China salah satu ekonomi dengan pertumbuhan tercepat dan ekonomi terbesar ketiga di dunia pada 2008 (Xiaolong dan Christensen, 2019). Bahkan Chow (2010) memprediksi pertumbuhan ekonomi China masih dapat bertahan di kisaran 8 persen per tahun setidaknya selama 10 sampai 15 tahun ke depan. Tentunya keberhasilan tersebut tidak terlepas dari bagaimana China mereformasi sistem kepegawaiannya dalam 3 dekade untuk menyelenggarakan pemerintahannya yang efektif.

Dengan demikian menjadi keniscyaan untuk mengetahui faktor apa saja yang menyebabkan reformasi sistem kepegawaiannya dapat terlaksana yang bermuara pada efektifnya penyelenggaran pemerintahan China. Untuk menganalisis keterkaitan efektifitas pemerintahan di
China dengan reformasi sistem kepegawaian negara setidaknya ada dua indikator dari enam indikator yang dijadikan sebagai penilaian.

Dengan menggunakan indikator yang dikeluarkan oleh Worldwide Governance Indicator (WGI) analisis yang diharapkan nantinya dapat lebih komprehensif dan lebih berpengaruh. Data dari WGI yang digunakan mencakup lebih dari 200 negara yang dinilai dan penilaian dilakukan mulai tahun 1996 sampai saat ini (Quibria, 2015:23). Keenam indikator tersebut ialah efektifitas pemerintahan, kebebasan berpendapat, dan akuntabiltitas, stabilitas politik dan rasa keamanan, kualitas peraturan perundangan, penegakan hukum, dan kontrol terhadap korupsi (Kaufmann, dkk; 2003\&2010).

Namun, analisis dalam penelitian ini hanya menunjukan bahwa upaya perbaikan reformasi kepegawaian negara China mulai dari dekade 1980-an sampai dengan dekade 2010-an membawa hasil positif terhadap efektifitas pemerintahan. 
Grafik 1. Kinerja Efektifitas Pemerintahan Pilihan Negara Asia, 2018

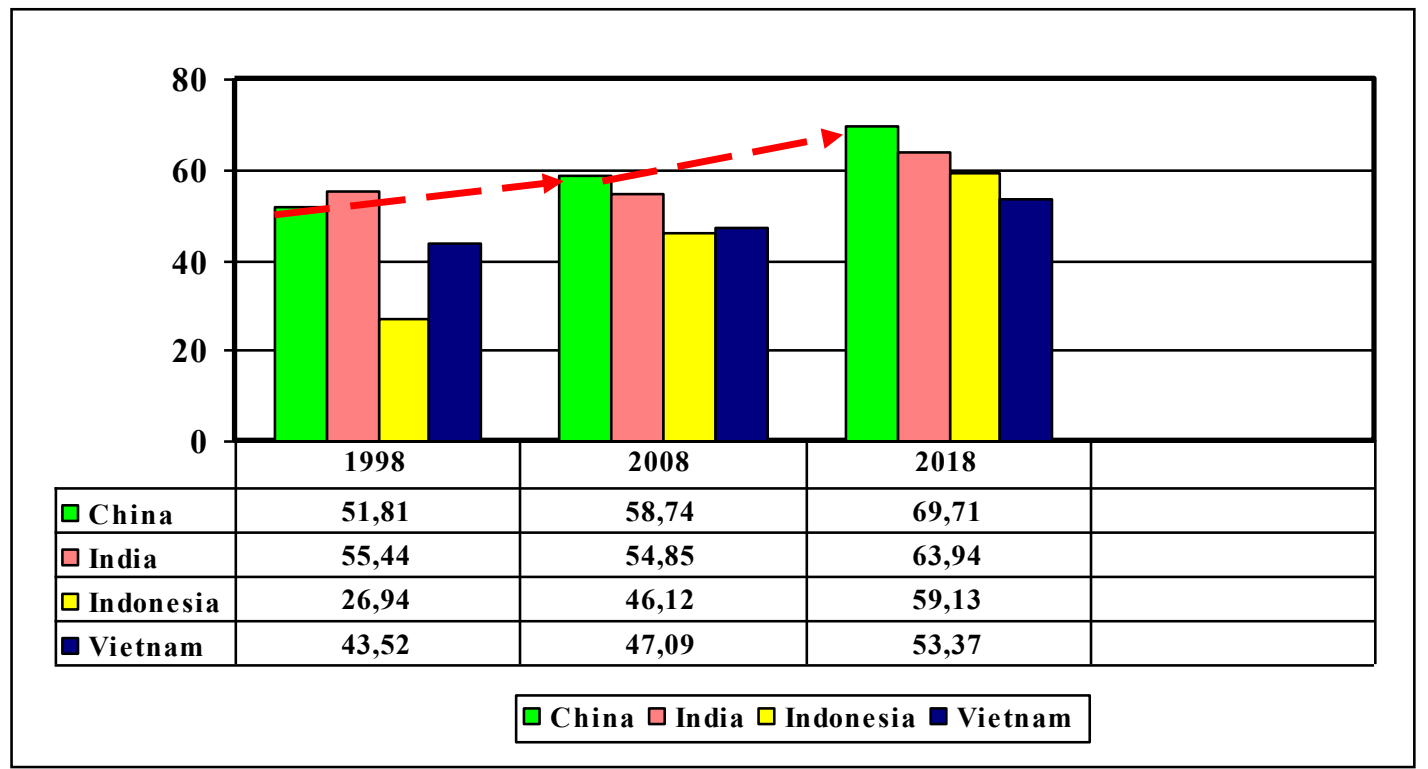

Sumber Gambar: World Bank, Worldwide Governance Indicator online database (accessed Maret 2020), diolah Peneliti 2020.

Menurut Quibria (2015:24) penilaian terhadap indikator efektifitas pemerintahan dilihat "which incorporates measures on the quality of public service provision and the bureaucracy, the insulation of the civil service from political presure and the credibility of the government commitment to policies”. Dari penjelasan di atas dapat diartikan sebagai berikut. Pertama, pemberian kualitas pelayanan publik terhadap masyarakat harus memudahkan masyarakat.

Kedua, PNS harus dapat keluar dari tekanan politik dalam pemberian pelayanan publik. Ketiga, kredibiltas atau kemampuan pemerintah untuk menjalankan kebijakan yang memang sudah diputuskan dengan baik. Tiga indikator ini yang menjadi concern Peneliti dalam menganalisis hasil pencapaian upaya pembenahan sistem kepegawaian China. Grafik 1 di atas menyajikan data lengkap dari tahun 1998 sampai dengan 2018 dalam melihat indikator efektfitas pemerintahan di beberapa pilihan negara asia. Data di atas menunjukan upaya pembenahan sistem kepegawain negara di China memang terlihat hasilnya setelah 30 tahun dilakukan. Artinya tidak ada cara yang 
Tabel 1. Rangking Pilihan Negara dengan Alternatif Indikator Penilaian, 2015

\begin{tabular}{cccc}
\hline & \multicolumn{3}{c}{ Alternatif Indikator Penilaian } \\
\cline { 2 - 4 } Negara & $\begin{array}{c}\text { Corruption } \\
\text { Perceptions Index, } \\
2013(177 \text { Negara })\end{array}$ & $\begin{array}{c}\text { Gompetitiveness } \\
\text { Index, 2014 (148 } \\
\text { Negara })\end{array}$ & $\begin{array}{c}\text { Ease of Doing } \\
\text { Business, 2014 } \\
\text { (189 Negara) }\end{array}$ \\
\hline China & 80 & 29 & 96 \\
\hline India & 94 & 60 & 134 \\
\hline Indonesia & 114 & 38 & 99 \\
\hline Vietnam & 116 & 70 & 120 \\
\hline
\end{tabular}

Sumber Tabel 1: Quibria, 2015 “Concepts, Measurements, Determinants, and a Paradox" dalam Anil B Deolalikar, Shikha Jha, dan Pilipinas F Quising, eds, Governance in Developing Asia Public Service Delivery and Empowerment, Hlm: 41.

instant atau cara cepat dalam menciptakan efektifitas pemerintahan Upaya pembenahan sistem kepegawaian sangat tidak mungkin dilakukan dengan kisaran waktu yang terbatas (5 atau 10 tahun) setidaknya membutuhkan 3 s.d. 5 dekade untuk mereformasi. Pencapaian China dalam mewujudkan efektifitas pemerintahannya melalui upaya mereformasi sistem kepegawaiannya sekiranya bisa mendapatkan pembelajaran berharga untuk negara lain. Dari tabel 1 di atas menunjukan dengan menggunakan alternatif indikator dalam penilaian lain yaitu dari Corruption Perception Index (CPI), Global Competitiveness Index (CGI), dan Ease of Doing Business Index (EODB) pada kisaran waktu 2013-2014.
Peringkat China menunjukan hasil yang cukup menjanjikan bila dibandingkan dengan negara asia yang lain. Paling tidak dari penilaian yang dilakukan oleh lembaga asing menunjukan bahwa upaya perbaikan sistem kepegawaian negara China membuahkan hasil. Pencapaian tersebut tentunya tidak terlepas dari bagaimana keberhasilan China membenahi sistem kepegawaian. Oleh karena itu, menjadi semakin menarik kiranya untuk mengetahui determinan keberhasilan apa saja yang ada dan pembelajaran baik apa saja yang dapat diadopsi dan diadaptasi oleh negara lain dalam mencapai keberhasilan mereformasi sistem kepegawaian. 


\section{METODE PENELITIAN}

Dalam penelitian ini, dilakukan dengan metode penelitian kualitatif. Metode penelitian kualitatif merupakan metode untuk mengekplorasi dan memahami makna yang oleh sejumlah individu atau sekelompok orang dianggap berasal dari masalah sosial (Creswell, 2017). Teknik analis yang digunakan adalah analisis deskriptif kualitatif dengan menganalisis (1) faktor penting yang mempengaruhi reformasi kepegawaian di China selama 3 dekade, (2) best practices apa yang dapat diadopsi oleh negara lain dalam menerapkan reformasi kepegawainnya. Metode pengumpulan data atau analisis isi yang dilakukan ialah melalui penelitian kepustakaan dan menelaah data sekunder (Irawan,2006). Data sekunder (Satori dan Komariah, 2011) merupakan sumber data yang tidak langsung memberikan data pada pengumpul data. Dengan demikian data sekunder yang ditelaah mengenai penelurusan kasus reformasi sistem kepegawaian China dari tahun 1980 sampai dengan 2010 dari sumber literature, dokumen, publikasi informasi, buku, jurnal, survei internasional, media massa baik dari surat kabar, atau berita online (website).

\section{HASIL PENELITIAN}

Hasil penelitian ini akan berusaha untuk mencoba menggambarkan dan menganalisis determinan faktor dari reformasi sistem kepegawaian di China periode 1980-2010, kebijakan keberhasilan reformasi kepegawaian, dan pembelajaran baik yang dapat diadopsi. Selanjutnya, pembahasan akan dituangkan dalam sub masing-masing. Dari hasil penelitian yang dituangkan pada tabel 2 di bawah ini menunjukan keterkaitan antara pembahasan dan hasil penelitian.

\section{PEMBAHASAN}

\section{Determinan Faktor Reformasi Sistem} Kepegawaian Negara China

China memiliki sejarah administrasi (kepegawaian negara) yang multimilleanial dan terbagi menjadi tiga tahapan publik (Jing, 2010:34-38) yaitu: administrasi kerajaan, administrasi negara, dan administrasi publik. Administrasi kerajaan di China (sebelum 1912) ditandai dimana kaisar sebagai pusat segalanya 
Tabel 2. Hasil Penelitian tentang Determinan Keberhasilan Proses Reformasi Kepegawaian

\begin{tabular}{|c|c|c|c|}
\hline No & $\begin{array}{c}\text { Determinan } \\
\text { Faktor }\end{array}$ & Deskripsi Hasil & Pembelajaran Baik \\
\hline 1 & Politik & $\begin{array}{l}\text { Kepemimpinan politik (Deng Xiao } \\
\text { Ping) yang kuat merupakan tonggak } \\
\text { awal dari upaya perubahan masif dan } \\
\text { 'radikal' yang dilakukan. Pemimpin } \\
\text { politik yang memiliki kharisma dan } \\
\text { melihat perubahan lingkungan global } \\
\text { yang cepat mengharuskan untuk } \\
\text { segera mengambil kebijakan politik } \\
\text { yang tepat. }\end{array}$ & $\begin{array}{l}\text { 1. Pollitical will dan pollitical } \\
\text { commitment dari seluruh } \\
\text { pimpinan negara menjadi } \\
\text { fondasi; } \\
\text { 2. Konsistensi setiap tingkatan } \\
\text { pimpinan dalam melakukan } \\
\text { perubahan yang dituju; } \\
\text { 3. Kapasitas pimpinan dalam } \\
\text { mengalisis dan meramal apa } \\
\text { yang harus dilakukan } \\
\text { kedepannya }\end{array}$ \\
\hline 2. & Hukum & $\begin{array}{l}\text { Peraturan perundangan yang terus } \\
\text { disempurnakan dan disesuaikan } \\
\text { dengan kondisi global dan } \\
\text { karakteristik negara menjadi } \\
\text { landasan dalam upaya pemebenahan } \\
\text { reformasi kepegawaian }\end{array}$ & $\begin{array}{l}\text { 1. Aturan main yang } \\
\text { komprehensif dan terus } \\
\text { disempurnakan: } \\
\text { 2. Supervisi dan pengawasan } \\
\text { dari aturan main } \\
\text { 3. Menjadikan aturan main } \\
\text { sebagai stabilator } \\
\text { penyelenggaraan } \\
\text { pemerintahan }\end{array}$ \\
\hline 3. & Birokrasi & $\begin{array}{l}\text { Pengurangan, penyesuaian, dan } \\
\text { penggabungan lembaga negara, } \\
\text { pembenahan proses seleksi birokrasi } \\
\text { dipemerintahan, pengurangan } \\
\text { birokrasi pemerintah serta } \\
\text { mendorong investasi yang besar } \\
\text { terhadap upaya pembenahan } \\
\text { birokrasi }\end{array}$ & $\begin{array}{l}\text { 1. Profesionalitas pegawai yang } \\
\text { berdasarkan kompetensi } \\
\text { 2. Penerapan merit sistem secara } \\
\text { bertahap dan konsisten } \\
\text { 3. Pembayaran gaji dan bonus } \\
\text { berdasarkan kinerja (pay for } \\
\text { merit system) }\end{array}$ \\
\hline 4. & Ekonomi & $\begin{array}{l}\text { Perubahan kebijakan ekonomi yang } \\
\text { strategis dan pragmatis, ekonomi } \\
\text { terbuka dengan dunia internasional } \\
\text { secara tidak sadar membawa } \\
\text { pengaruh terhadap standar birokrasi } \\
\text { yang disesuikan dengan investor } \\
\text { asing yang menanamkan inevestasi } \\
\text { (penyederhanaan izin, kemudahan } \\
\text { proses perizinin, dlsb) }\end{array}$ & $\begin{array}{l}\text { 1. Kebijakan Pragmatis } \\
\text { pemimpin negara } \\
\text { 2. Kebijakan pembangunan } \\
\text { ekonomi yang langsung } \\
\text { terlihat nyata (infrastruktur) } \\
\text { 3. Standar internasional dalam } \\
\text { penyelenggaran pemerintahan } \\
\text { (ekonomis. Efektif, efisien, } \\
\text { dan equlity). }\end{array}$ \\
\hline
\end{tabular}

Sumber Tabel 2: hasil olahan Peneliti, 2020 
birokrasi harus setia kepada kaisar adalah hal yang pertama dan utama. Administrasi negara di China (1912-1978) tidak terlepas dari pertarungam dua ideologi yaitu demokrasi dan sosialis (Lan dan Chen, 2010). Akibatnya, sistem administrasi utamanya dilayani otoritas negara lewat Leninist Party dan berfungsi sebagai instrumen perjuangan politik. Sedangkan, administrasi publik di China (setelah 1978) ialah dimana administrasi lebih terbuka kepada dunia luar dan mau mengadopsi kebijakan dari luar. Fokus tulisan ini berusaha menganalisis permasalahan birokrasi China setelah 1978 atau mulai memasuki dekade 1980-an.

Permasalahan mendasar kepegawaian di China tidak terlepas dari seleksi, promosi, korupsi, dan evaluasi kinerja kepegawaian (Burns 1987: 48 dan Dong, Yang, dan Wang 2010: 110). Reformasi kepegawaian negara China pada dasarnya merubah sistem kepegawaian negara yang bersifat tradisional (sistem kader partai) kearah yang bersifat modern (Burns,1989). Ada empat faktor penting yang mempengaruhi sistem kepegawaian di China. Keempat faktor tersebut ialah: politik, hukum, birokrasi, dan ekonomi. Keempat faktor penting tersebut dianalisis dilihat dari moment penting yang terjadi dalam upaya China melakukan upaya penataan sistem kepegawaian negaranya. Keempat faktor itu tentunya sangat saling terkait satu sama lain. (Zhang dan Zhou, 2010:145-160).

Pertama, faktor politik disini dapat dijelaskan bahwa dukungan politik dari sebuah rezim sangat mempengaruhi dalam upaya mereformasi sistem kepegawaian. Faktor kepemimpinan Deng Xiao Ping (selanjutnya disebut Deng) pada dekade 1970-an sampai dengan 1990-an merupakan tonggak awal dari upaya perubahan sistem kepegawaian di China. Deng sangat menyadari untuk menciptakan kemajuan atau memoderinasi china ke arah yang kesejahteraan, kunci utamanya ialah bagaimana melakukan restrukturisasi kelembagaan (Ngok dan Zhu, 2007). Baik itu kelembagaan di partai maupun di negara. Deng menyadari bahwa terlalu 'gemuk'nya lembaga negara, menyebabkan lambannya birokrasi berjalan. Berawal dari Pidato Deng Xiao Ping pada bulan Agustus 1981 mengecam seluruh pejabat termasuk PNS China, terutama pejabat yang aktif di pemerintahan beliau menyatakan: 
"Fenomena birokrasi saat ini adalah masalah yang paling serius dan akut bagi bangsa dan partai. Birokrasi saat ini: memandang rendah masyarakat, menyalahgunakan kekuasaan politik, PNS dengan jumlah besar, menghindari pengambilan keputusan, ketidakpedulian terhadap efisiensi, tidak bertanggung jawab, mengkhianati kepercayaan masyarakat, menekan demokrasi, serta subordinasi, menerima suap, dan memperkaya diri sendiri". (Lee 1983; dalam Zhang dan Zhou, 2010)

Pidato Deng seolah seperti membangunkan para pejabat China. Pemerintah China menjalankan untuk mengimplementasikan peraturan perundang-undangan reformasi administrasi dan dua bulan setelah pidato pada Januari 1982 disahkan pada Maret 1982. Dampak dari reformasi kepegawaian di China ialah nampak pada tiga tingkatan pemerintahan: pemerintah pusat, provinsi, dan kota atau kabupaten. Di tingkat pusat, badan pemerintah dikurangi dari 100 menjadi 61 dan pegawai pemerintah di tingkat pusat (badan pemerintah) dikurangi dari 51.000 menjadi 31.000 PNS. Artinya ada 39 badan pemerintah dan pegawai berkurang 18.000 ribu pegawai. Di tingkat provinsi, lembaga administratif dikurangi dari sebelumnya 60 menjadi hingga 30 dan pegawai pemerintah provinsi dikurangi dari
180.000 menjadi 120.000. Selanjutnya, pada tingkatan ketiga di tingkat kota atau kabupaten, pegawai pemerintah diperkecil sekitar $20 \%$. Selanjutnya usia rata-rata para pejabat setingkat menteri berkurang dari 64 menjadi 60 dan usia rata-rata pemimpin tingkat biro (juji) dikurangi dari 58 menjadi 54. Artinya para menteri pada saat itu dipaksa harus pensiun pada umur 60 tahun dan pejabat pemerintah dipaksa untuk pensiun pada usia 54 Tahun. Hal ini untuk memberikan kesempatan kepada PNS yang lebih muda untuk aktif dan berperan. Selain perubahan ini, lama waktu pemimpin atau para pejabat yang dihabiskan untuk mendapatkan pendidikan dan pelatihan meningkat (Liu 1998 dalam Zhang dan Zhou, 2010). Tidak kalah pentingnya Deng juga menekankan bagaimana prinsip seperti policy outcome benefits, administrative efficiency, dan socioeconomic advancement menjadi dasar dalam menjalankan pemerintah di China (Choi, 2018). Prinsip itu menjadikan penyelenggaran pemerintahan dapat berjalan seperti corak atau karakteristik dari China (lihat tabel 2). 
Tabel 3. Reformasi Kepegawaian China Dekade 1980-an

\begin{tabular}{|c|c|c|}
\hline Periode & Upaya Reformasi & Hasil \\
\hline $\begin{array}{l}\text { 1982-1987 } \\
\text { (Reformasi 1982) }\end{array}$ & $\begin{array}{l}\text { 1. Perampingan Organisasi } \\
\text { (Downsizing) } \\
\text { 2. Penyederhanaan Proses } \\
\text { (Streamlining) } \\
\text { 3. Reorganisasi } \\
\text { 4. Menerapkan usia pensiun } \\
\text { 5. Menambah tenaga } \\
\text { profesional pada Birokrasi }\end{array}$ & $\begin{array}{l}\text { 1. Lembaga Negara } \\
\text { berkurang dari } 100 \text { (tahun } \\
\text { 1981) menjadi } 72(1982) \\
\text { 2. Pegawai negeri di lembaga } \\
\text { negara berkurang dari } 51.000 \\
\text { (tahun 1982) menjadi } 31.000 \\
(1983) \text {. }\end{array}$ \\
\hline $\begin{array}{l}\text { 1988-1992 } \\
\text { (Reformasi 1988) }\end{array}$ & $\begin{array}{l}\text { 1. Perampingan Organisasi } \\
\text { (Downsizing) } \\
\text { 2. Reorientasi Fungsi } \\
\text { Organisasi } \\
\text { 3. Pemisahan kader partai dan } \\
\text { birokrasi } \\
\text { 4. Pemisahan birokrasi dan } \\
\text { perusahan negara } \\
\text { (enterprises) }\end{array}$ & $\begin{array}{l}\text { 1. Lembaga negara berkurang } \\
\text { dari } 72 \text { menjadi } 61 \\
\text { 2. Mendirikan kementerian } \\
\text { yang khusus untuk } \\
\text { mensupervisi perubahan } \\
\text { birokrasi terkait kinerja dan } \\
\text { etika } \\
\text { 3. Mendirikan kementerian } \\
\text { aparatur negara terkait } \\
\text { reformasi kepegawaian }\end{array}$ \\
\hline
\end{tabular}

Sumber Tabel 3: dikutip dari Ngok, Kinglun dan Zhu, Guobuin. (2007). "Marketization, Globalization, and Administrative Reform in China: a zigzag road to promising future. International Review of Administrative Sciences. Hal: 222.

Pollitical will dan pollitical commitment sangat terasa dalam reformasi yang dilakukan dengan pendekatan comprehensive strategy (Lee, 1970:14-18). Kepemimpinan politik (Deng) tidak hanya sekedar gelisah dan geram terhadap keadaan namun juga harus memberikan contoh suri teladan yang baik (Dwiyanto, 2016:70-76). Deng sudah menunjukan kepada kita bahwa pemimpin tertinggi yang harus merubah, mengambil tanggung jawab, dan menggerakan untuk membawa ke arah yang lebih baik dari suatu negara.

Dari tabel 4 di bawah ini dapat terlihat bahwa secara garis besar upaya reformasi pada dekade 1990-an menekankan kepada 4 (empat) hal yaitu bagaimana menyelarasakan fungsi pemerintahan, menyederhanankan birokrasi, memberikan batasan kekuasaan pada organ pemerintah, dan memperkuat peraturan perundangan terkait reformasi kepegawaian (Ngok dan 
Zhu, 2007). Hal penting lainnya ialah bagaimana keberlanjutan dari upaya reformasi kepegawaian yang dilakukan. Dekade 80-an dan diteruskan pada dekade 90-an memiliki kesamaan kebijakan inti.
Hal ini dapat diartikan kebijakan yang telah dilakukan memiliki konsistensi dalam keputusan yang telah di tempuh China.

Tabel 4. Reformasi Kepegawaian China Dekade 1990-an

\begin{tabular}{|c|c|c|}
\hline Periode & Upaya Reformasi & Hasil \\
\hline $\begin{array}{l}\text { 1993-1997 } \\
\text { (Reformasi 1993) }\end{array}$ & \multirow{3}{*}{$\begin{array}{l}\text { 1. Penggabungan lembaga } \\
\text { negara } \\
\text { 2. Penyesuaian peringkat } \\
\text { lembaga negara } \\
\text { 3. Mengurangi jumlah } \\
\text { lembaga ekonomi khusus } \\
\text { 4. Melaksanakan State } \\
\text { Ownership Enterprises } \\
\text { 5. Sosialisasi peruturan } \\
\text { sementara pegawai negeri } \\
\text { sipil tahun } 1993\end{array}$} & \multirow{3}{*}{$\begin{array}{l}\text { 1. Lembaga negara } \\
\text { berkurang dari } 86 \rightarrow 61 \rightarrow 59 \\
\text { 2. PNS pada pemerintahan } \\
\text { pusat berkurang } 20 \text { persen } \\
\text { 3. Perubahan dan } \\
\text { penggabungan lembaga } \\
\text { negara agar efektif }\end{array}$} \\
\hline Lanjutan Tabel 3 & & \\
\hline & & \\
\hline \multirow{9}{*}{$\begin{array}{l}\text { 1998-2002 } \\
\text { (Reformasi 1998) }\end{array}$} & 1. Penyerderhanaan & 1. Lembaga negara kembali \\
\hline & 2. Perampingan & berkurang dari $59 \rightarrow 53 \rightarrow$ \\
\hline & 3. Korporatisasi & menjadi 51 pada tahun \\
\hline & 4. Penggabungan & 1998 \\
\hline & $\begin{array}{l}\text { 5. Memperkuat pengawasan } \\
\text { 6. Menghilangkan }\end{array}$ & $\begin{array}{l}\text { 2. Jumlah Dewan Negara } \\
\text { berkurang dari } 40 \rightarrow 29\end{array}$ \\
\hline & $\begin{array}{l}\text { kementerian yang tidak } \\
\text { efektif }\end{array}$ & $\begin{array}{l}\text { pada tahun 1998; } \\
\text { 3. } 15 \text { Kementerian yang }\end{array}$ \\
\hline & $\begin{array}{l}\text { 7. Memperkuat penegakkan } \\
\text { hukum }\end{array}$ & $\begin{array}{l}\text { berhubungan dengan } \\
\text { perinsdutrian dihilangkan }\end{array}$ \\
\hline & $\begin{array}{l}\text { 8. Reorientasi fungsi } \\
\text { lembaga negara }\end{array}$ & $\begin{array}{l}\text { 4. Memperkuat lembaga } \\
\text { perencanaan dan }\end{array}$ \\
\hline & $\begin{array}{l}\text { 9. Meningkatkan peran } \\
\text { pemerintahan dalam } \\
\text { jaminan sosial warga }\end{array}$ & $\begin{array}{l}\text { pembangunan negara } \\
\text { 5. Jumlah PNS mengalami } \\
\text { pengurangan }\end{array}$ \\
\hline
\end{tabular}

Sumber Tabel 3: dikutip dari Ngok, Kinglun dan Zhu, Guobuin. (2007). "Marketization, Globalization, and Administrative Reform in China: a zigzag road to promising future. International Review of Administrative Sciences. Hal: 225. 
Kedua, faktor hukum. Dalam upaya mereformasi kepegawaiannya mulai mengedepankan dan menguatkan prinsip rule of law (Luo, 1998 dan Straussman dan Zhang, 2001:414-415). Antara tahun 1980an sampai akhir tahun 1990-an, sistem hukum di China mulai berubah dimana awalnya hukum sebagai alat negara dan partai, menjadi bahwa hukum digunakan untuk mengatasi hambatan pemerintahan serta mulai berfokus menekankan kepada hak-hak individu. (Xiaolong dan Christensen, 2019: 860). Hal ini sejalan dengan ppendapat Xue dan Zhong (2012) bahwa Reformasi administrasi yang dilakukan oleh China yang dilakukan dari tahun 1980-an sampai saat ini tentunya didasari oleh supermasi hukum yang yang tidak lagi berbasis pada pemimpin negara dan partai.

Hal ini diimplementasikan melalui terbitnya "Peraturan Sementara tentang Pegawai Negeri Sipil" pada tahun 1993 (The Provisional Regulations on State Civil Servant). Pada prinsipnya untuk mereformasi kepegawaian yang begitu banyak masalah diperlukan UU tersebut. Masalah tersebut antara lain ialah mengenai analis pekerjaan birokrasi, rekruitment pegawai, reward and punishment, disiplin pegawai, proses mutasi, rotasi, promosi, demosi, pensiun, pemberian gaji dan mulai ada upaya pengembangan pegawai (Lam \& Chan, 1995; Tsao \& Worthley, 1995 dalam Liou, Xue dan Dong, 2012). UU 1993 menekanan pada akuntabilitas dan efisiensi dengan menyasar pada peningkatan pertumbuhan ekonomi. Pada 2002, mulai dilakukan penyempurnaan dengan UU Kepegawaian Negara China yang kurang lebih isi peraturannya sama dengan yang sebelumnya namun praktek meritrokrasi sangat ditekankan. Pada akhir tahun 2005, setelah 12 tahun UU itu diimplementasikan akhirnya UU Kepegawaian Negara China diterbitkan (The Law of Civil Servants). Setidaknya hal teknis yang di atur dalam UU tersebut mengenai bagaimana pengelolan pegawai negeri sipil mulai dari rekrutmen, penilaian pegawai, rotasi, mutasi, promosi, dan demosi, pelatihan pengembangan pegawai, serta reward and punishment mulai disempurnakan untuk dilaksanakan setelah tahun 2005 (Zhang dan Zhou, 2010). Bahkan dalam UU ini sudah mengatur bagaimana pemberian bonus berdasarkan penilaian kinerja. 
Sistem pemberian kinerja di dasarkan pada 4 kategori yaitu pembayaran berdasarkan jabatan, pembayaran terhadap pengalaman kerja, tunjangan kemahalan, dan pemberian bonus berdasarkan kinerja (Meng dan $\mathrm{Wu}, 2015$ ). Bisa dikatakan 2 (dua) UU itu merupakan payung hukum atau tonggak perubahan China dalam mereformasi kepegawaian yang dapat mendorong pertumbuhan ekonomi. Selain itu, upaya penguatan hukum dalam dua dekade terakhir ialah bagaimana tata kelola pemerintahan dan adminsitrasi pemerintahan mulai berdasarkan aturan perundangan. Upaya itu pun dilakukan dengan memperkuat kementerian atau departemen penegakan hukum dan pengawasan (Xiaolong dan Christensen, 2019). Artinya tidak hanya perangkat hukum saja yang diciptakan namun struktur yang mendorong dan memperkuat penegakan hukum juga penting untuk dibentuk. Hal tersebut untuk memastika agar reformasi yang dilakukan berada pada jalur yang tepat

Ketiga, faktor birokrasi. Mulai tersadarnya bahwa perubahan harus dimulai dari dalam diri birokrasi sendiri (people), mereka menyadari bahwa profesionalitas mulai dikedepankan. Lima bulan setelah pidato Deng Xiao Ping (Agustus, 1981). Selanjutnya, pada Januari 1982, Deng kembali menunjukan kegeramannya terhadap kondisi kepegawaian di China. Deng menyadari bahwa kondisi permasalahan ekonomi (kemiskinan) dan korupsi yang dihadapi di China tidak akan mungkin dapat dihadapi dengan kapasitas birokrasi yang ada seperti saat ini. Bagi Deng kondisi birokrasi seperti ini tidak bisa dibiarkan begitu saja. Deng menyatakan bahwa:

"Perampingan organ administrasi adalah sebuah revolusi, "dengan alasan bahwa "badan pemerintah terlalu gemuk atau besar dan berlebihan, tersusun tidak efektif, dan tugas tidak jelas. Banyak orang tidak memenuhi syarat menjadi PNS. Mereka bukan PNS yang memiliki kapasitas yang sesuai. Masyarakat tidak akan mentolerir kondisi saat ini dan pemerintahan pun saat ini tidak akan mentoleransi keadaan seperti ini terus" (Deng 1998: dalam Zhang dan Zhou, 2010).

Birokrasi harus diberikan pendidikan pelatihan secara baik, perekrutan birokrasi harus lebih kompetitif, perlu dilakukan motivasi, dan ada upaya evaluasi terhadap pengukuran kinerja pegawai (Jing dan Zhu, 2012). Sistem merit mulai diterapkan 
secara serius seperti halnya merestrukturisasi kelembagaan negara yang terlalu besar, mendesentralisasikan kekuasaan, melakukan memoderinasikan pemerintahan, dan focus on streamlining government institutions (Guo, 2017:360). Selain itu, China mulai menunjukan keseriusannya dalam merekrut aparatur negarnya. Ujian saringan masuk pegawai negeri pun dibuat semakin sulit yang mana lebih menekankan kepada kompetensi dan keahlian serta ketrampilan (Xiaolong dan Christensen, 2019). Upaya ini dilakukan semata-mata untuk memastikan bahwa orang yang menjadi aparatur negara merupakan putra-puteri terbaik yang dimiliki oleh China. Selanjutnya, pada tahun 2005 meminjam istilah dari Deng Xiaoping birokrasi harus "more revolutionary, better educated, younger and professionally more competent." These include organizations in charge of civil service management, recruitment, training, performance appraisal, compensation, and rewards and punishment" (Zhou, 2010).

Pada tahun 2008 kelanjutan reformasi administrasi kepegawaian yang dilakukan ialah dipisahkannya sistem pemerintahan menjadi 3 pilar kekuasaan yaitu kekuasaan untuk mengambil keputusan (termasuk perencanaan), pelaksanaan kebijakan, dan supervisi atau pengawasan (Xue dan Zhong,2012)

Tabel 5. Restrukturisasi Kementerian dan Lembaga China (1978-2008)

$\begin{array}{ccccc}\text { Tahun } & \text { Kementerian/ } & \text { Lembaga di } & \text { Total Lembaga } & \text { Pengurangan Pegawai } \\ \text { Komisi Negara } & \text { Kementerian } & \text { Negara } & \begin{array}{c}\text { Pemerintah } \\ \text { Kom }\end{array}\end{array}$

\begin{tabular}{ccccc}
\hline $\mathbf{1 9 7 8 - 1 9 8 1}$ & & 100 & $51.000 \rightarrow 38.300$ \\
\hline $\mathbf{1 9 8 2}$ & 45 & 16 & 61 & $50.000 \rightarrow 40.000$ \\
\hline $\mathbf{1 9 8 8}$ & 41 & 19 & 60 & $37.000 \rightarrow 29.600$ \\
\hline $\mathbf{1 9 9 3}$ & 41 & 18 & 59 & $32.000 \rightarrow 16.700$ \\
\hline $\mathbf{1 9 9 8}$ & 29 & 23 & 52 & \\
\hline $\mathbf{2 0 0 3}$ & 28 & 23 & 51 &
\end{tabular}

Sumber Tabel 5: dikutip dari Xue dan Zhong (2012). Domestic reform and global integration: public administration reform in China over the last 30 years, dalam International Review of Administrative Sciences. Vol 78. No. 2. HIm: 280 
Hal ini penting dilakakukan agar penyelenggaraan pemerintahan dapat berjalan lebih effektif dan efisien, serta mekanisme check and balances mulai dibangun. Selain itu yang tidak kalah pentingnya pada tahun ini profesionalitas para birokrasi mulai semakin terus dikembangkan. Selain itu yang tidak kalah pentinganya pada Tahun 2009 mulai diinisiasi peningkatan remunerasi di landasi dengan kinerja (the pay for merit system). Dalam hal ini performance based salaries mulai diterapkan di birokrasi China. Penyesuaian remunerasi ini menjadi penting untuk dilakukan untuk meningkatkan kinerja dan kreativitas para birokrat di China (Meng and $\mathrm{Wu}, 2015$ ). Walaupun, upaya pembenahan remunerasi telah diriintis mulai tahun 2005, namun penyempurnaan pemberian renumerasi terus dilakukan agar para birokrasi menjadi semakin tertantang dan termotivasi untuk menciptakan perubahan penyelenggaran pemerintahan.

Keempat, faktor ekonomi. Kepemimpinan Deng Xiao Ping China berubah menjadi negara yang tidak hanya berfokus stabilitas pemerintahan tetapi juga untuk mengejar pertumbuhan ekonomi sekaligus menciptakan negara China yang pragmatis (Vietor, 2007:62-65 dan Choi, 2018). Bergabungnya China dengan World Trade Organization (WTO) pada 2001 merupakan sebuah langkah besar, karena ini merupakan kebijakan pintu terbuka China dimana investasi atau aliran dana yang masuk ke China semakin bertambah (Chow, 2010). Sebelum itu juga, pada dekade 90-an dana asing yang masuk ke China, ditengarai merupakan hal yang mendorong pertumbuhan ekonomi mencapai di atas 10 persen, perubahan drastis (keterbukaan ekonomi) inilah yang kemudian menjadi fondasi China untuk terus berkembang (Cipto, 2018)

Hal ini nampak pada tahun 2003 bahwa poin utama reformasi yang dilakukan oleh China ialah dengan melalukan berbagai upaya perubahan ekonomi. Mereformasi sistem pengelolaan aset negara, meningkatkan dan memperkuat sistem keuangan negara, penguatan perdagangan internasional, dan mendorong pembentukan sistem regulasi ketahanan pangan (Xiaolong dan Christensen, 2019: 859). 
Selain itu selama dua atau tiga dekade terakhir, pemerintahan dengan sistem yang tertutup mulai bergeser ke arah bagaimana pemberian tanggungjawab tersebar tidak hanya pada negara saja tetapi ke beragam aktor negara seperti pemerintaha, sektor swasta, dan masyarakat (Lockwood, 2010: 762).

Lebih jauh Lockwood (2010) menjelaskan faktor-faktor yang mendorong tersebut antara lain mencakup pemahaman yang lebih besar tentang peran masyarakat dalam bentuk pemerintahan, kesadaran budaya dan sosial masyarakat lokal yang dimiliki, mulai adanya pengakuan terhadap hak asasi manusia, timbulnya pengakuan hak orang untuk memiliki suara dalam keputusan yang mempengaruhi mereka, dan timbulnya kekuatan ekonomi politik yang mengarah pada pendekatan yang lebih mirip bisnis (dalam Rahayu dan Juwono, 2018). Dalam konteks faktor ekonomi secara jelas menggambarkan bagaimana sistem kepegawaian negara harus mampu berdaptasi dengan nilai-nilai ekonomi (efisiensi, ekonomis, dan efektivitas) sebagai upaya menarik investor dan mengejar pertumbahan ekonomi.

\section{Kebijakan Dalam Mereformasi Kepegawaian Negara Di China}

Bila melihat konteks pemerintahan China yang terdesentralisasi maka menjadi sebuah kenicayaan jika lima kebijakan atau agenda reformasi kepegawaian di bawah ini dilakukan untuk dapat memperbaiki reformasi kepegawaian negara yang berada di pusat dan daerah. Sehingga lima kebijakan ini mencakup seluruh pemerintahan level manapun di China. Setidaknya ada 5 (lima) kebijakan operasional yang dilakukan oleh pemerintah China dalam melakukan reformasi kepegawaian China (Zhang dan Zhou, 2010, Liou, Xue dan Dong, 2012, dan Jing dan Zhu, 2012).

Pertama, melakuan pengkelompokan posisi jabatan hal ini dilakukan untuk mengetahui analisis beban kerja yang dilakukan, pengukuran kinerja, evaluasi kinerja yang dilakukan, serta untuk menenentukan pembayaran gaji yang sesuai. Setidaknya ada tiga kategori pengkelompokan posisi jabatan dalam pegawai negeri yaitu manejerial komprehensif, teknokrat, dan administratif. Dalam pelaksanannya harus sesuai dengan 
sifat, karakteristik, dan manajemen kebutuhan posisi pegawai negeri. Kedua, kompensasi pegawai di China Sistem kompensasi pegawai negeri China didasarkan pada pangkat dan jabatan. Gaji dasar seorang pegawai negeri dibagi menjadi dua kategori: gaji pokok dan peringkat gaji; posisi gaji terutama merupakan tanggung jawab seorang warga sipil pelayan. Selain itu ada juga bonus. Bonus diberikan berdaarkan lokasi kerja, daerah geografis, dan sistem yang diterapkan. Bonus diberikan setiap akhir tahun apabila penilaian kinerja memuaskan di akhir tahun. Bonus diberikan sebesar satu kali gaji pokok sebulan. Ketiga, pelatihan setidaknya ada empat aspek dalam mewujudkan hal tersebut yaitu pendirian badan pendidikan dan pelatihan secara masif, kurikulum pendidikan harus terus disesuaikan dengan perubahan jaman saat ini, isi pelatihan harus untuk meningkatkan tujuh kemampuan dasar, dan metode pembelajaran harus dengan best practice untik dapat diadopsi.

Keempat, pengukuran kinerja dan evalusi pegawai negeri sipil. Pegawai negeri harus dievaluasi terkait loyalitasnya, kemampuan, ketekunan, kinerja, dan bebas korupsi. Dimana fokusnya adalah pada pencapaian kinerja yang telah ditetapkan sebelumnya. Hasil penilaian rutin dibagi menjadi empat penilaian yaitu: sangat baik, memuaskan, biasa, dan tidak memuaskan. Hasilnya dikirim ke PNS dalam format tertulis. Hasil ini menjadi referensi penting untuk menyesuaikan posisi selanjutnya, ranking, dan grade hal ini berimplikasi terhadap pemberian bonus, pemgikutsertaan dalam pelatihan, bahkan sampai pemecatan.

Kelima, sistem pensiun pegawai negeri China. Kondisi pensiun dibedakan dalam dua hal yaitu memang wajib pensiun atau mengajukan diri untuk pensiun dini. Rata-rata usia pensiunan PNS di China untuk laki-laki ialah 60 tahun dan 55 tahun untuk wanita. Namun untuk pejabat setingkat menteri dapat pensiun diatas 65 tahun. Sesudah pensiun mendapatkan uang gaji pokok setiap bulannya dan bila gaji PNS aktif naik maka para pensiunan menikmati kenaikan gaji pula. Selain itu pensiunan mendapatkan perawatan medis yang dicover oleh asuransi kesehatan negara. Selain itu bisa mendapatkan satu rumah (tergantung setiap daerah), transportasi umum yang gratis, dan gratis 
biaya pengurusan kematian dan pengurusan pemakaman.

Dari kelima kebijakan tersebut merupakan turunan dari determinan faktor keberhasilan yang telah dijelaskan sebelumnya. Keempat determinan faktor yang sudah dijelaskan lebih dijabarkan kembali lewat dari lima kebijakan tersebut. Dari faktor dan upaya tersebut maka menghasilkan kepegawaian negara China yang efektif terhadap penyelenggaran pemerintahan. Berdasarkan analisis di atas dapat disimpulkan bahwa dalam reformasi kepegawaian negara, subsistem yang harus direformasi secara sistematis adalah subsitem perekrutan, kompensasi, pengukuran kinerja, promosi, dan pengawasan etika dan perilaku. Semua upaya tersebut membutuhkan kesadaran dan komitmen politik dari semua entitas di suatu negeri (Prasojo, 2009:97-98). Melihat keberhasilan China dalam mereformasi sistem kepegawaiannya, tentunya ada pembelajaran baik yang dapat diadopsi dari proses reformasi yang berjalan. Selanjutnya, dalam sub bagian di bawah ini akan dianalisis pembelajaran baik apa yang dapat disesuaikan oleh setiap negara.

\section{Pembelajaran Baik dari China}

Dari penjabaran di atas setidaknya ada beberapa pembelajaran dalam melakukan transformasi kepegawaian di China. Setidaknya ada 4 (empat) pembelajaran yang dapat di analis, diamati, dan tentunya dikondisikan sesuai dengan karakteristik dari setiap negara. Keajaiban yang dialami China, tentu saja membuat bangsa lain bertanya-tanya apa yang dapat membuat China dapat melakukan "lompatan katak" (leapfrogging). Bahkan dipredikasi 20 tahun dari sekarang China akan menggantikan Amerika menjadi negara super power (Cipto, 2018). Empat pembelajaran itu diantaranya ialah sebagai berikut: Pertama, perubahan yang masif bahkan radikal yang langsung dikomandoi oleh pimpinan tertinggi suatu negara terbukti cukup memberikan multiplier effect perubahan ke sektor yang lain.

Pimpinan tertinggi tidak hanya menunjukan kegeramannya saja terhadap kondisi yang ada, namun memujudkan dengan aksi nyata dengan segala perubahan kebijakan yang masif dan terstruktur. Selain itu ialah konsistensi dari pimpinan untuk mewujudkan perubahan untuk membawa kemajuan dan kesejahteraan 
negaranya juga menjadi faktor penting. Konsistensi untuk mengambil keputusan dan melaksanakan kebijakan yang dianggap tidak populis. Tetap dilakukan untuk mencapai kemajuan.

Adanya perubahan tongkat estafet terbukti tidak menjadi faktor penghalang dari perubahan yang terus digelorakan oleh para pimpinan untuk mencapai masa kejayaan negaranya. Selain itu ialah kapasitas pemimpin untuk dapat berpikir strategis dan pragmatis dalam membaca arah perkembangan global juga menjadi penting. Bakan Deng berkata "Since the reform and openining up Deng Xiaoping emphasized for many times that leaders should look at the world, look at the future and work at all aspects" (Wu dan Jingjun, 2018). Kapasitas pimpinan dibutuhkan dalam mengamati dan menganalisis sejauh mana kebijakan yang diambil oleh suatu negara dalam mendorong kesejahteraan suatu negaranya.

Kedua, perubahan birokrasi tanpa dipayungi oleh sistem hukum menyebabkan perubahan yang akan dituju menjadi tidak berdasar. Pembelajaran yang dapat di ambil dari poin ke dua ialah bahwa perubahan apa pun dalam sektor pemerintahan membutuhkan kebijakan publik yang unggul yang tertuang dalam suatu perundangan. Dari China setidaknya kita belajar untuk memulai suatu perubahan yang besar diperlukan suatu perangkat hukum yang terus menerus untuk selalu disempurnakan. Membutuhkan 12 tahun China untuk memperbaiki UU sistem kepegawaian nya agar dapat tersus disesuaikan dengan kultur dan karakteristik dari birokrasi China. Selain itu, tidak kalah pentingnya ialah bagaimana supervisi dan pengawasan dari pelaksanaan UU sistem kepegawaiannya terus dilakukan. Selain itu payung hukum juga digunakan untuk menjaga stabilitas negara. Reformasi dan pembangunan yang dilakukan oleh suatu negara tanpa adanya stabilitas politik dan sosial, maka akan rawan menjadi konflik. Oleh karena itu menjaga stabilitas dalam payung hukum menjadi hal yang mutlak untuk diperlukan. Ketiga, sumber daya manusia. China memahami bahwa birokrasi yang kompeten dan profesional adalah mesin penggerak dari upaya China untuk merengkuh kejayaannya. Pilihan kebijakan apa pun yang diambil oleh pimpinan dan sebaik apa pun kebijakan yang diformulasikan 
menjadi tidak berarti apa bila street level bureauceacy nya tidak mampu mengejawantahkan apa yang diinginkan dalam kebijakan. Investasi besar China terhadap upaya pembenahan birokrasinya perlu menjadi pembelajaran. Birokrasi yang berkualitas menjadi syarat mutlak untuk China dapat mendorong kemajuan yang tercapai saat ini. Selain itu yang tidak kalah pentingnya birokrasi China juga selalu dituntut untuk menciptakan inovasi yang dapat mempermudah penyelenggaran pemerintahan.

Keempat, upaya pembenahan ekonomi dibarengi dengan upaya pembenahan birokrasi. Prinsip penyelenggaraan negara yang dilakukan secara ekonomis, efektif, dan efisien merupakan prinsip ekonomi yang mulai diterapkan di sektor publik. Dengan terlibatnya China ke dalam komunitas internasional tidak dapat dinaffikan adanya standar internasional atau transformasi dari organisasi internasional iktu mempemngaruhi birokrasi China berubah (Jing, 2010) Keterbukaan ekonomi China dengan mendatangkan investor asing ke China. Pada akhirnya menuntut birokrasi China harus bersikap adaptif terhadap keterbukaan ekonomi. Tanpa adanya perubahan kebijakan ekonomi yang terbuka, maka upaya reformasi kepegawaian China sulit diwujudkan. Dengan kata lain perubahan kebijakan ekonomi China, turut mendorong birokrasi China ikut berbenah. Selain itu yang tidak kalah pentingnya upaya pembangunan infrastruktur yang nyata membuat kepercayaan masyarakat yakin bahwa pembangunan ekonomi China sudah berada pada jalur yang tepat. Tentunya dari keempat pembelajaran tersebut tidak dapat dilepaskan dari bentuk pemerintahan China yang sosialis. Dengan bentuk pemerintahan yang seperti itu tentunya memudahkan dalam mewujudkan efektifitas penyelenggaran pemerintahan. Namun disisi lain, Peneliti juga tidak dapat menafikkan upaya 'radikal' yang dilakukan China untuk memperbaiki birokrasi China. Setidaknya upaya yang dilakukan selama 3 (tiga) dekade terakhir dari tahun 1980-2010 menunjukan upaya pembenanan birokrasi (reformasi kepegawain) China menjadi fondasi utama dalam menciptakan keajaiban ekonomi China. Bahkan, bukan hal yang mustahil usaha pembenahan birokasi China yang diawali dari tahun 
1980 dapat menghantarkan China menjadi negara super power.

\section{KESIMPULAN}

Kesimpulan penelitian "Determinan Keberhasilan Reformasi Sistem Kepegawaian di China Periode 1980-2010 ialah bahwa: Ada empat deterimanan faktor yang mempengaruhi reformasi sistem kepegawaian negara Terhadap Efektifitas Pemerintahan dan Kontrol Terhadap Korupsi Negara China dari Tahun 1980 sampai dengan 2010 yaitu: faktor politik, faktor hukum, faktor birokrasi, dan faktor ekonomi. Keempat faktor tersebut saling terkait satu sama lain dalam usaha China melakukan reformasi sistem kepegawaian negara. Efektifitas pemerintahan mengalami penilaian trend positif bila dikaitkan dengan reformasi sistem kepegawain negara di China dengan hampir nilai 70 (versi WGI). Artinya reformasi sistem kepegawaian negara di China yang dimulai pada dekade 80-an, membawa dampak positif terhadap efektifitas pemerintahan dengan nilai 70 (tahun 2018). Pembelajaran baik yang dapat diadopsi dari setiap faktor ialah (1) faktor politik seperti komitmen, konsistensi, dan kapasitas pimpinan (2) faktor hukum seperti; penciptaan aturan main, pengawasan, dan penciptaan stabilitas, (3) faktor birokrasi seperti: profesionalitas, penerapan system merit, dan peningkatan kesejahteraan, dan (4) faktor ekonomi seperti: pemilihan kebijakan yang pragmatis dan pembangunan ekonomi yang mendorong investasi. Ketiga hasil tersebut lah yang Peneliti analisis dari penelitian yang telah dilakukan. Pada prinsipnya setiap reformsasi atau tranformasi membutuhkan waktu dalam pencapaian. Tidak ada hasil yang instant, karena pada hakekatnya reformasi penyelenggaraan pemerintah it's never ending process. Saran yang dapat diuraikan dari penelitian "Determinan Keberhasilan Reformasi Sistem Kepegawaian di China Periode 1980-2010 ialah bahwa: Pastikan seluruh entitas pimpinan di setiap level pemerintahan (pusat dan daerah) untuk dapat memiliki satu visi dan misi dalam upayanya mereformasi kepegawaiannya. Artinya komitmen, konsistensi, dan keteguhan pimpinan menjadi landasan paling utama dalam setiap memulai transformasi 
organisasi, karena setiap perubahan tidak mungkin dilakukan dalam waktu yang sekejap (it's never ending process. Selain itu kapasitas pimpinan menjadi penting untuk menentukan arah dan memimpin langsung setiap perubahan yang diharapkan serta menyusun dan mengimplementasikan setiap kebijakan (perangkat hukum dalam upaya perubahan. Investasi yang besar terhadap sumber daya manusia (birokrasi) menjadi hal yang diperlukan. Pengembangan professional, kapasitas, dan peningkatan kesejahteraan birokrasi merupakan suatu kesatuan yang tidak dapat dipisahkan atau saling terkait. Berbicara professional dan kapasitas sulit rasanya bila tidak dibarengi dengan kesejahteraan birokrasi. Tentunya investasi yang besar diartikan kesejahteraan birokrasi pemerintahan yang cukup (the pay for merit system). Investasi yang besar ini pun tidak luput dari bagaiman sistem merit mampu diterapkan secara holistik dan komprehensif.

\section{REFERENSI}

Burns, John. P. (1989). Chinese Civil Service Reform: The $13^{\text {th }}$ Party Congress Proposals. China Quartely 120: 739-770.
Burns, John. P. (1987). China Nomenklatura System. Problems of Comunism 36 (5): 36-51.

Cipto, Bambang. (2018). Strategi China Merebut Status Super Power. Yogyakarta: Pustaka Pelajar.

Choi, Franky K.H. (2018). "How to establish a good government? Lesson from Lee Kuan Yew in Singapore and Deng Xiaoping in China" dalam Journal Public Administration and Policy. Vol. 21. No. 2. Hlm: 107-119.

Chow, Gregory C. (2010). Memahami Dahsyatnya Ekonomi China. (Terj). Rahmani Astuti. Solo: Metagraf, Tiga Serangkai.

Creswell, John W (2017). Research Design: Pendekatan Kualitatif, Kuantitatif, dan Mixed. (Terj). Achmad Fawaid. Edisi Keempat. Cet2. Yogyakarta: Pustaka Pelajar.

Dong-Ke Yong, Hong-Shan, Xiaohu Wang (2010). "Public Service Ethics and Anticorruption Efforts in Mainland China" dalam Evan M Berman, M Jae Moon, dan Heungsuk Choi, eds, Public Administration in East Asia: Mainland China, Japan, South Korea, and Taiwan. Taylor and Francis: Boca Rotan, Florida.

Dwiyanto, Agus. (2016). Memimpin Perubahan di Birokrasi Pemerintahan Catatan Seorang Kritis Seorang Akademisi. Yogyakarta: Gajah Mada University Press.

Hao, Yufan dan Johnston, Michael. (2007). "Corruption and The Future of Economic Reform in China" dalam 
Arnold J Heidenheimer and Michael Johnston, eds, Political Corruption Concepts and Contexts. Third Edition. New Jersey: Transaction Publishers.

Heritage Foundation (2014), “2014 Index of Economic Freedom Online Database" available at http://www.heritage.org/indexexplore.

Irawan, Prasetya (2006). Penelitian Kualitatif dan Kuantitatif untuk IlmuIlmu Sosial. Depok: Departemen Ilmu Administrasi-FISIP UI.

Jing, Yijia. (2010). "History and Context of Public Administration Mainland China" dalam Evan M Berman, M Jae Moon, dan Heungsuk Choi, eds, Public Administration in East Asia: Mainland China, Japan, South Korea, and Taiwan. Taylor and Francis: Boca Rotan, Florida.

Jing, Yijia dan Zhu, Qianwei. (2012). Civil Service Reform In China: An Unfinished Task Of Value Balancing, dalam Review of Public Personnel Administration. Vol 32. No.2. Hlm. 134-148.

Kaufmann, D., A. Kraay, dan M. Mastruzzi. (2003) "Governance matters III governance indicators for 1996-2002", World Bank Policy Research Working Paper No. 3106, Washington, DC: World Bank.

Kaufmann, D., A. Kraay, dan M. Mastruzzi. (2010) "The Worldwide Governace Indicators: Methodology and Analitical Issues", World Bank Policy Research Working Paper No. 5430, Washington, DC: World Bank.
Lockwood, Michael. 2010. Good Governance For Terrestial Protected Areas: A Framework, Principles, and Performances Outcomes. Journal of Environmental Management. 91, Hlm: 754-766.

Lan, G Zhiyong dan Chen, Guoquan. (2010). "Intergovernmental Relations in Mainland China" dalam Evan M Berman, M Jae Moon, dan Heungsuk Choi, eds, Public Administration in East Asia: Mainland China, Japan, South Korea, and Taiwan. Taylor and Francis: Boca Rotan, Florida.

Liou, Tom Kuotsai, Lan Xue, dan Keyong Dong. (2012). "China Administration and Civil Service Reform: An Introduction. Review of Public Administration. No. 32. Vol.2. Hlm: 108-114.

Meng, Fanrong dan Wu, Jiannan. (2015). "Merit Pay Fairness, Leader-Member Exchange, and Job Engagement: Evidence From Mainland China" dalam Review oof Public Personnel Administration. Vol. 35. No.1. Hlm: 47-69.

Ngok, Kinglun dan Zhu, Guobuin. (2007). "Marketization, Globalization, and Administrative Reform in China: a zigzag road to promising future. International Review of Administrative Sciences. No.73. Vol.2 Hlm: 218-232.

Prasojo, Eko. (2009). Reformasi Kedua Melanjutkan Estafet Reformasi. Jakarta: Salemba Humanika.

Quibria, M.G. (2015). "Concepts, Measurements, Determinants, and a Paradox" dalam Anil B Deolalikar, 
Shikha Jha, dan Pilipinas F Quising, eds, Governance in Developing Asia Public Service Delivery and Empowerment. Asian Development Bank. Metro Manila: Edwar Elgar Publishing.

Rahayu, Amy Y.S dan Vishnu Juwono. (2018). Birokrasi dam Governance: Teori, Konsep, dan Aplikasinya. Depok: Raja Grafindo Persada.

Satori, Djam'an da Komariah, Aan. (2011). Metodologi Penelitian Kualitatif. Cet ketiga. Bandung: CV Alfa Beta.

Vietor, Richard H.K. (2007). How Countries Compete: Strategy, Structure, and Government In Global Economic.

Wu, Jiang dan Jingjun, Shao. (2018). "Leadership and Public Sectro In China" dalam Evan Berman dan Eko Prasojo, ed, Leadership and Public Sector Reform in Asia. London: Emerald Publishing Limited.

Xiaolong, Tian dan Christensen, Tom. (2019). "Beyond NPM to Post NPM? A Study of China's Covernment Reforms Over the Past 40 Years, dalam American Review of Public Administration. Vol 49. No. 7. Hlm 855-865.

Xue, Lan dan Zhong, Kaibin. (2012). Domestic reform and global integration: public administration reform in China over the last 30 years, dalam International Review of Administrative Sciences. Vol 78. No. 2. Hlm: 284-304.

Zhang, Mengzhong dan Wei Zhou. (2010). "Civil Service Reform in Mainland China" dalam Evan M Berman, M Jae Moon, dan Heungsuk Choi, eds, Public Administration in East Asia: Mainland China, Japan, South Korea, and Taiwan. Taylor and Francis: Boca Rotan, Florida.

Zhou, Zhiren. (2010) Performance mangement Reform in Mainland China" dalam Evan M Berman, M Jae Moon, dan Heungsuk Choi, eds, Public Administration in East Asia: Mainland China, Japan, South Korea, and Taiwan. Taylor and Francis: Boca Rotan, Florida. 